\title{
Synthesis and Biological Properties of Novel Fluoroprostaglandin Derivatives: Highly Selective and Potent Agonists for Prostaglandin Receptors
}

\author{
Yasushi Matsumura ${ }^{a^{*}}$, Takashi Nakano ${ }^{\mathrm{b}}$, Nobuaki Moria ${ }^{\mathrm{a}}$, and Yoshitomi Morizawa ${ }^{\mathrm{b}}$
}

Abstract: Synthesis of novel 7,7-difluoroprostacyclin and 15-deoxy-15,15-difluoro-PGF ${ }_{2 \alpha}$ derivatives will be presented. These compounds show high affinity to prostaglandin receptors and potent biological activities.

Keywords: Antiplatelet · Fluorination · Glaucoma · Prostaglandin · Receptor

\section{Introduction}

Fluorine-containing molecules have attracted much attention recently in medicinal chemistry because fluorine has unique physical properties such as small atomic size, strong electron negativity, and high carbon-fluorine bond energy [1]. Introduction of fluorine atoms into a variety of biologically important substances, e.g. steroids [2], amino acids and peptides [3], and nucleosides [4], often brought significant improvement in their pharmacological profiles. A series of prostaglandin (PG) derivatives are particularly attractive targets for us because of their biological importance and a broad range of therapeutic applicability as medicines [5]. Recent advance in mo-

\footnotetext{
${ }^{*}$ Correspondence: Dr. Y. Matsumuraa

Tel.: + 81436233671

Fax: + 81436233672

E-Mail: Yasushi-Matsumura@agc.co.jp

aFine Chemicals Group

Chemicals Company

Asahi Glass Co., Ltd.

10 Goikaigan

Ichihara-shi, 290-8566, Japan

${ }^{b}$ Research Center

Asahi Glass Co., Ltd.

1150 Hazawa-cho

Yokohama, 221-8755, Japan
}

lecular biology unveils novel physiological functions of PG receptors [6]. According to cDNA cloning and structural elucidation of PG receptors, exploratory research of new PG receptor agonists has been largely accelerated [7]. In this article synthesis and some biological properties of novel difluorinated PG derivatives will be presented. It gives an impression of the large applicability and possibilities of a geminal difluoride moiety as one of the key units in drug design to transform physical and biological properties.

\section{Fluorinated Prostacyclin Derivatives}

Since the discovery of prostacyclin $\left(\mathrm{PGI}_{2}\right)$ by Vane and coworkers in 1976 [8], which is an unstable metabolite of arachidonic acid in the vascular cell wall, research related to prostacyclin has been extensively developed. Prostacyclin, a member of the PG family, has powerful actions as an antiplatelet agent which prevents platelet aggregation, and as a vasodilator which increases blood flow and produces hypotension. However, therapeutic applications of natural prostacyclin are very limited due to its inherent chemical and metabolic instability (Fig. 1). A large number of stabilized analogs have been reported, and some have been used in clinical trials or marketed as powerful agents for ischaemic peripheral vascular disease, Raynaud's disease, and primary pulmonary hypertension [5]. Recently, the structures and main functions of
PG receptors have been characterized [6]. It is reported that natural prostacyclin and its agonists such as iloprost [9] and beraprost [10] have strong affinities not only for the IP receptor (prostacyclin receptor) but also for the EP1 receptor (one of the four PGE receptor (EP) subtypes) [11]. Further research seeking for more selective prostacyclin agonists is needed to elucidate the diverse functions of these receptors and the overall mechanism of signal transduction at the molecular level, and also to obtain potentially valuable drugs without undesirable side effects.

Our study has been focused on novel prostacyclin derivatives fluorinated at the 7 -position, particularly $7 \alpha$-fluoroprostacyclin (1) and 7,7-difluoroprostacyclin (AFP07) (2) (Fig. 1). The strong electron-withdrawing effect of fluorine atoms adjacent to the acid-sensitive enol ether should be particularly effective in protecting against hydrolysis.

The monofluoroprostacyclin $\mathbf{1}$ bearing a cyclobutyl group was synthesized by a three-component coupling approach [12] or by use of methylenecyclopentanone [13]. It exerted potent antiplatelet and anti-anginal activities in animal models in oral administration [14]. Next, we targeted a difluoroprostacyclin 2 to study the contribution of the second fluorine atom to the stability and biological activity. Retrosynthesis of AFP07 in both Route A and B was featured by difluorination of the Corey lactone and Wittig reaction of the difluoro lactone (Scheme $1)$. 
Degradation of Natural Prostacyclin
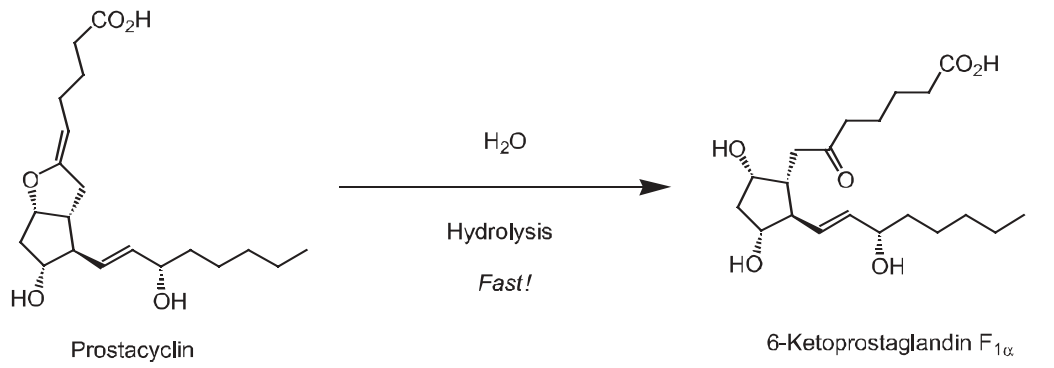

6-Ketoprostaglandin $F_{1 \alpha}$

Fluorinated Prostacyclin Analogs

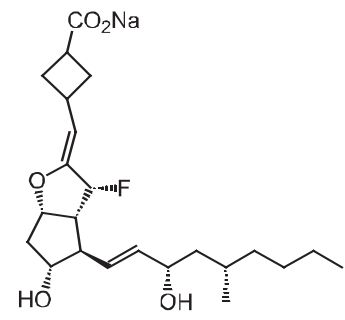

$7 \alpha-$ Fluoroprostacyclin (1)

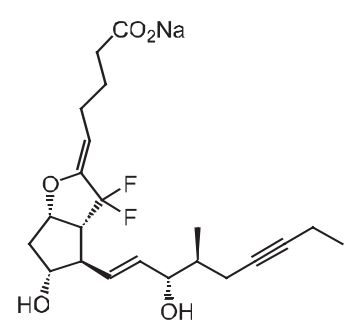

AFP-07 (2)

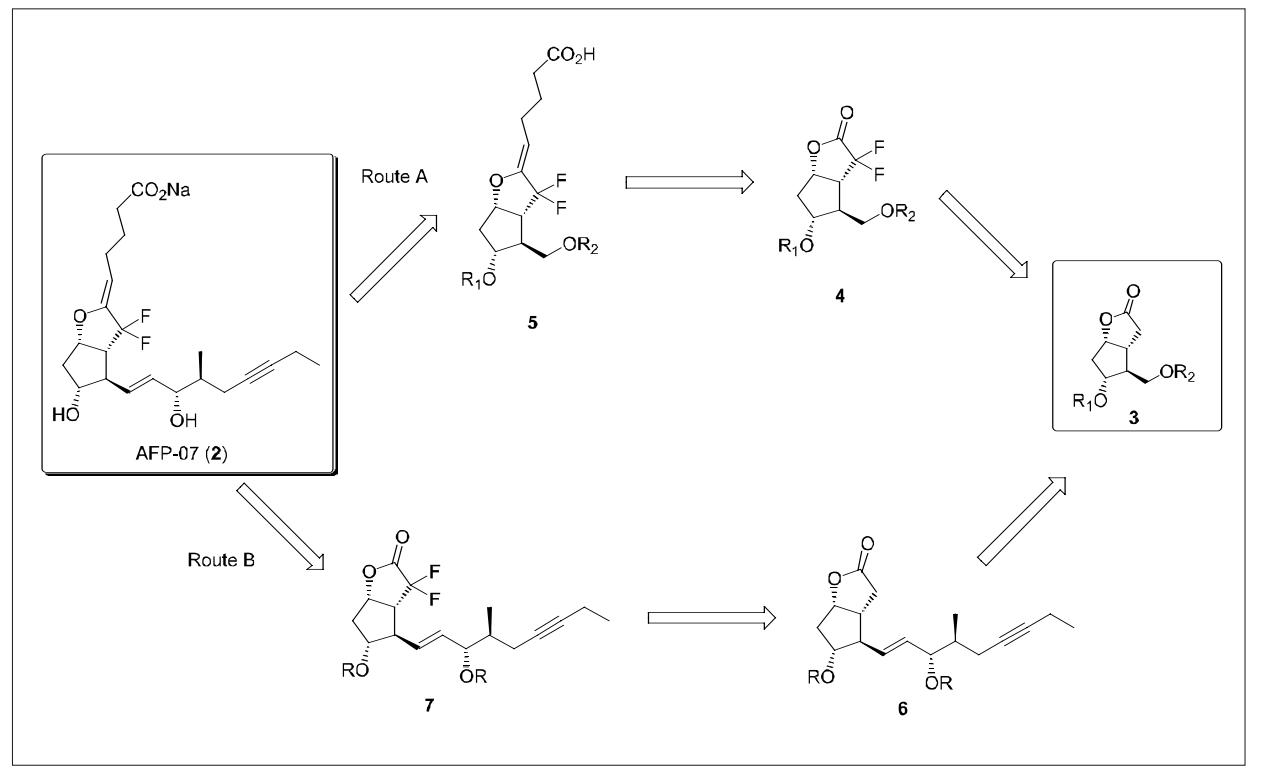

Electrophilic fluorination is an attractive method to synthesize fluorinated building blocks from rather complicated molecules. Several new electrophilic fluorinating agents have been developed [15], however, selective difluorination of the $\alpha$ position of carbonyl compounds remains an unsolved issue. We examined various fluorinating agents and found $\mathrm{N}$-fluorobenzensulfonimide [11b] with manganese dibromide to be suitable for the reaction of ketones and esters (Table 1). Applying this method, the Corey lactone $\mathbf{3}$ was converted to the difluorolactone $\mathbf{4}$ in $57 \%$ yield and the vinyl ether $\mathbf{5}$ was subsequently obtained by Wittig reaction as a 87:13 mixture of the $(Z)$ and $(E)$ isomers according to the Route A [16].
Because separation of the $(E)-5$ isomer became a problem for scale-up, we further studied the Wittig reaction of the difluorolactone 7 in the Route B. It was supposed that the steric bulkiness of the side chain should affect the selectivity of the Wittig reaction. The synthesis of the difluorolactone $\mathbf{1 1}$ is shown in Scheme 2.

The Corey lactone $\mathbf{8}$ was transformed to the enone 9 in 75\% yield by Moffatt oxidation, Horner-Emmons reaction with the known phosphonate [17], and deprotection of the THP group. Reduction with diisobutylaluminum 2,6-di(tert-butyl)-4methylphenoxide [18] gave a 91:9 mixture of the $(S)$ and $(R)$ diastereomers. After protection of the diol with tert-butyldimethylsilyl groups, fluorination of the
Fig. 1. Degradation of natural prostacyclin and fluorinated prostacyclin analogs lactone $\mathbf{1 0}$ with N-fluorobenzensulfonimide in the presence of manganese dibromide gave the desired difluoride $\mathbf{1 1}$ in $67 \%$ yield. Wittig reaction of $\mathbf{1 1}$ with the phosphonium salt and sodium N,Nbis(trimethylsilyl)amide in THF at $0{ }^{\circ} \mathrm{C}$ furnished the vinyl ether 12, as a 99.5:0.5 mixture of the desired $(Z)$ and $(E)$ isomers in 50\% yield (Scheme 3). After removal of tert-butyldimethylsilyl group in $\mathrm{AcOH} / \mathrm{THF} / \mathrm{H}_{2} \mathrm{O}$ and salt formation with $\mathrm{NaOH}$, the desired AFP-07 (2) was obtained in $95 \%$ yield.

The half lives of prostacyclin derivatives in an aqueous solution are shown in Table 2 . The stability of fluorinated prostacyclin derivatives, especially AFP-07 (2) is extraordinarily increased compared to nat- 
Table 1. Difluorination of ketones and esters

$$
\mathrm{R}^{1} \mathrm{R}^{2}
$$$$
\begin{aligned}
& \mathrm{MnBr}_{2} \text { (4.0 equiv.) } \\
& \left(\mathrm{PhSO}_{2}\right)_{2} \mathrm{NF}(4.0 \text { equiv.) } \\
& \mathrm{KN}\left(\mathrm{SiMe}_{3}\right)_{2} \text { (3.0 equiv.) }
\end{aligned}
$$

substrate difluorinated product<smiles>COC(=O)C(F)(F)c1ccccc1</smiles><smiles>O=C1c2ccccc2CCC1(F)F</smiles>

80 $>98: 2$

complex mixture

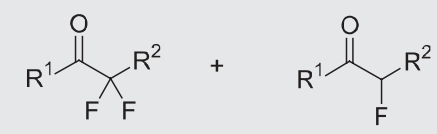

yield [\%] selectivity (di:mono)

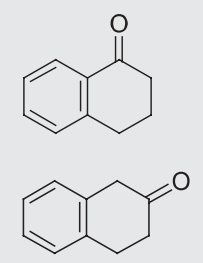

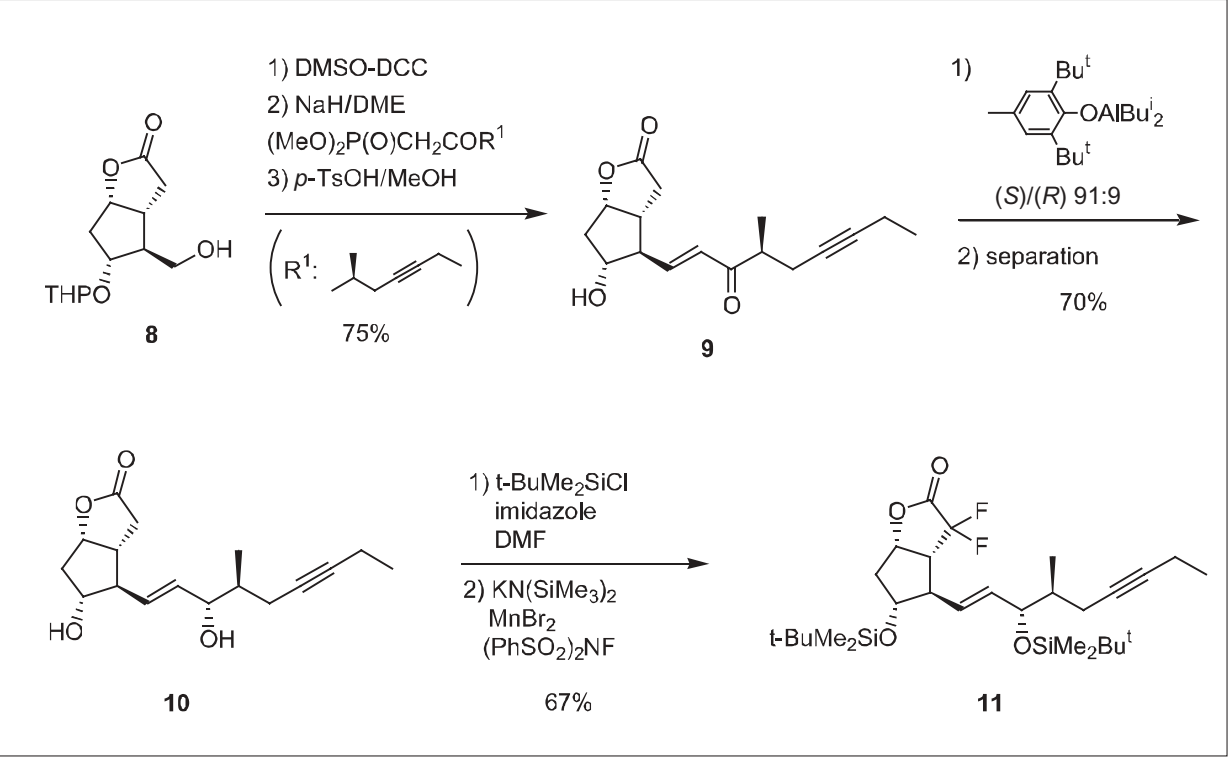

Scheme 2. Synthesis of difluorolactone $\mathbf{1 1}$

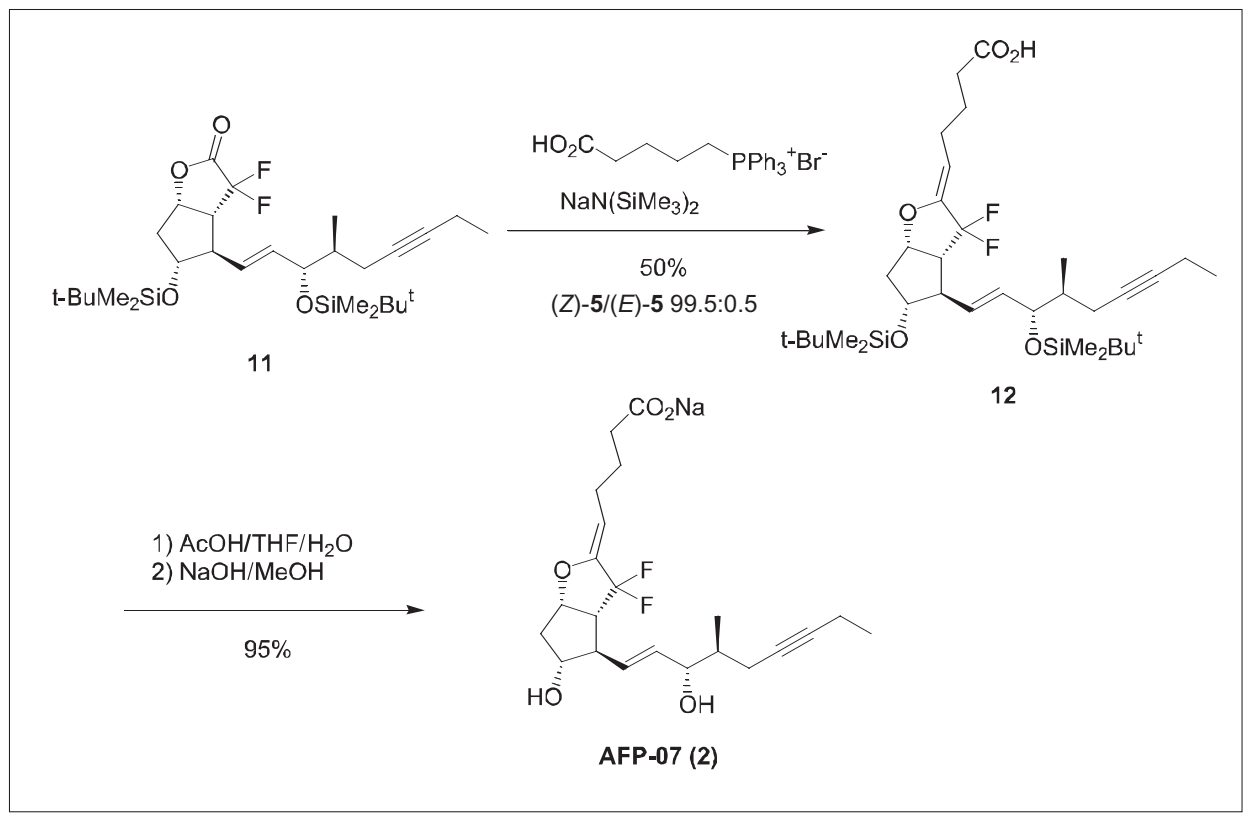

Scheme 3. Stereoselective Wittig reaction ural prostacyclin. Protonation of the double bond in the vinyl ether, the rate-limiting step in the hydrolysis, should be strongly retarded by the adjacent difluoromethylene group of 2 [19].

The inhibitory activity of the derivatives on ADP-induced human platelet aggregation in vitro is indicated as a relative potency to $\mathrm{PGE}_{1}$ in Table 2 . The activity of $\mathbf{2}$ is much higher than that of natural prostacyclin. In the binding study to $\mathrm{PG}$ receptors, 2 shows a very strong affinity for IP receptor with little affinity for four kinds of the PGE receptor (EP) subtype [20].

As for animal models in vivo, in the microcirculation of the hamster cheek pouch oral administration of 2 at 1 or $10 \mu \mathrm{g} / \mathrm{kg}$ produced a maximum percentage inhibition of ADP-induced thrombi of $27 \%$ and $39 \%$, respectively [21]. Oral dosage of AFP-07 (2) at $40 \mu \mathrm{g} / \mathrm{kg}$ twice a day prevented chronic hypoxic pulmonary hypertension in rats exposed to a simulated altitude of $17,000 \mathrm{ft}$ for 28 days [22].

\section{Fluorinated PGF $_{2 \alpha}$ Derivatives}

Glaucoma is one of the most common, but serious eye diseases that gradually steals sight without warning and often without symptoms. Vision loss is caused by damage to the optic nerve. The main risk factor is thought to be high intraocular pressure (IOP). Since the discovery that $\mathrm{PGF}_{2 \alpha}$ reduces intraocular pressure in an animal model [23], extensive efforts have been dedicated to develop PGF receptor (FP) agonists as new antiglaucoma agents [24]. Latanoprost, the representative FP agonist, has been first developed and widely used for the treatment of glaucoma [24b]. However, long-term application of the drug causes chronic adverse effects, such as iris/skin pigmentation [25]. In the search for a new FP agonist having more potent IOP reducing activity and weaker side effects than latanoprost, we have recently found 15-deoxy-15,15-difluoro-PGF $2 \alpha$, AFP-168 which shows highly potent affinity to the prostanoid FP receptor (Fig. 2) [26].

A synthetic route to AFP-168 (18) is shown in Scheme 4. The synthesis started from the Corey aldehyde 13 [27], which was converted to the enone $\mathbf{1 5}$ by HornerEmmons reaction with the phosphonate $\mathbf{1 4}$ [28]. Although a geminal difluoride unit has drawn more attention recently in medicinal chemistry, there is no general method to prepare an allyl difluoride from the corresponding enone efficiently [29]. We studied the fluorination reaction and found that reaction of the enone $\mathbf{1 5}$ with morpholinosulfur trifluoride [30] and successive deprotection of the benzoyl group with potassium carbonate in $\mathrm{MeOH}$ gave the geminal diflu- 
Table 2. Half life in saline and inhibitory effects on human platelet aggregation in vitro of protacylin derivatives

\begin{tabular}{|c|c|c|}
\hline Compounds & Half life in saline ${ }^{a}$ & $\begin{array}{l}\text { Inhibitory effects on human } \\
\text { platelet aggregation in vitro } \\
\left(\mathrm{PGE}_{1}=1\right)^{\mathrm{c}}\end{array}$ \\
\hline Prostacyclin & $10 \mathrm{~min}$ & 10 \\
\hline $7 \alpha$-Fluoroprostacyclin (1) & $2-3 h^{b}$ & $3-13$ \\
\hline AFP-07 (2) & $>90 \mathrm{~d}$ & 237 \\
\hline
\end{tabular}

${ }^{a} 25^{\circ} \mathrm{C}, \mathrm{pH} 7$, conc. $10 \mu \mathrm{g} / \mathrm{ml}$. ${ }^{\text {b }} 37^{\circ} \mathrm{C}, \mathrm{pH} 7$, conc. $2 \mu \mathrm{g} / \mathrm{ml}$. ${ }^{\mathrm{C}}$ Relative potency, $\mathrm{ADP}=2 \mu \mathrm{M}$
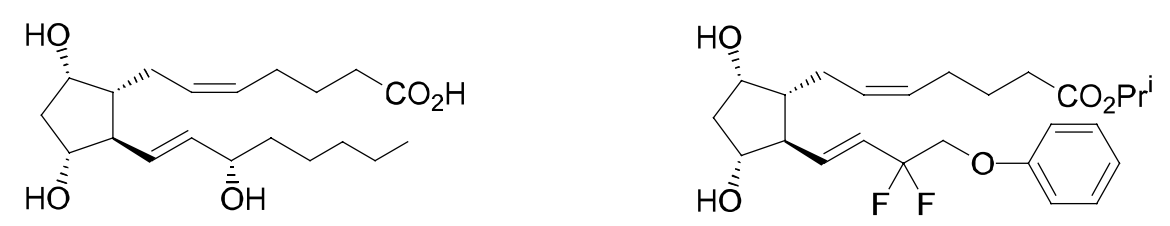

Prostaglandin $\mathrm{F}_{2 \alpha}$

AFP-168

Fig. 2. Prostaglandin $F_{2 \alpha}$ derivatives
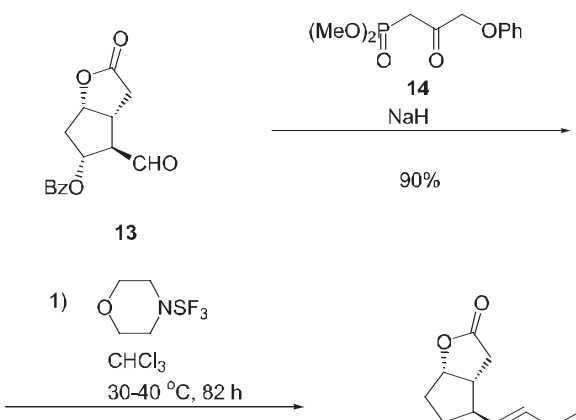

2) $\mathrm{K}_{2} \mathrm{CO}_{3} / \mathrm{MeOH}$ $\mathrm{rt}, 3 \mathrm{~h}$

$71 \%$

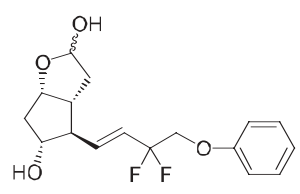

17

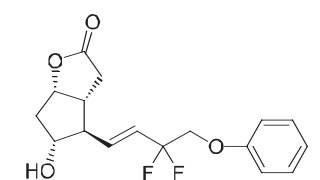

16

1) $\mathrm{Br}^{\cdot} \mathrm{Ph}_{3} \mathrm{P}^{+} \sim \mathrm{CO}_{2} \mathrm{H}$

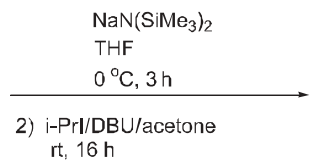

$72 \%$
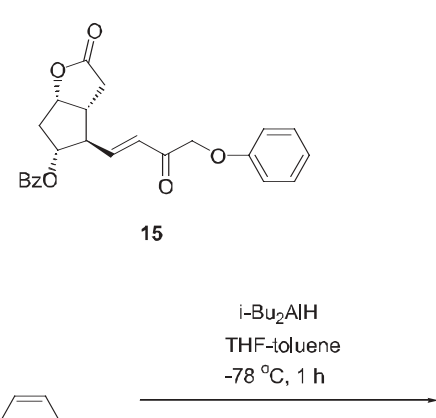

$83 \%$

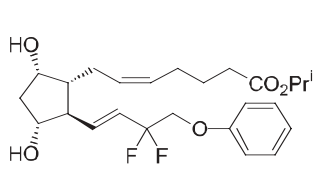

18 (AFP-168)

Scheme 4. Synthesis of AFP-168 (18)

oride 16 in 71\% yield. Reduction of the lactone $\mathbf{1 6}$ with diisobutylaluminum hydride in THF-toluene afforded lactol 17 in 83\% yield.

Wittig reactions of lactol 17 with the ylide prepared from 4-carboxybutyltriphenylphosphonium bromide with various bases yielded the 15-deoxy-15,15-difluoro$\mathrm{PGF}_{2 \alpha}$ derivative as a 5- $(Z) / 5-(E)$ mixture. Using sodium bis(trimethylsilyl)amide in tetrahydrofuran at $0{ }^{\circ} \mathrm{C}$, the $(Z) /(E)$ stereoselectivity became 99:1. Wittig reaction and the successive esterification of the crude acid treated with isopropyl iodide and 1,8diazabicyclo[5.4.0] undec-7-ene (DBU) in acetone afforded the desired 15-deoxy15,15-difluoro-PGF $2 \alpha$ isopropyl ester $\mathbf{1 8}$ (AFP-168) in $72 \%$ yield [31].
The affinity for the FP receptor of the corresponding carboxylic acid of AFP-168 was $0.4 \mathrm{nM}$ [26], which was 12 times higher than that of latanoprost [24b]. It should be noted that substitution of the hydroxyl group at the 15-position of $\mathrm{PGF}_{2 \alpha}$ by this novel 15,15-difluoro-moiety maintains an inherent nature to bind to the prostaglandin receptor with such high affinity. Because other modifications at 15-position often caused loss or reduction of affinity to prostaglandin receptors, the hydroxyl group seemed to be necessary to show pharmacological activity before [5]. In cultured melanoma cells, a carboxylic acid of latanoprost has been reported to increase melanogenesis [32]. However, a carboxylic acid of AFP-168 did not show the stimulatory effects on melanin content in cultured B16-F10 melanoma cells [33]. It is supposed the application of AFP-168 may cause less pigmentation than latanoprost. AFP-168 has a potent intraocular pressure reducing effect in animal models [26] and proceeds to clinical trial.

\section{Conclusions}

Synthesis and biological properties of novel 7,7-difluoroprostacyclin (AFP-07, 2) and 15-deoxy-15,15-difluoro-PGF ${ }_{2 \alpha}$ (AFP$168,18)$ derivatives are presented. Further studies of these $\mathrm{PG}$ agonists are in progress as potential new drugs. New approaches using geminally difluorinated building blocks in drug design are important tools to improve the physical and pharmacological profiles.

\section{Acknowledgments}

The authors thank Dr. Yasutaka Takagi, Mr. Tadashi Nakajima, Mr. Atsushi Shimazaki, Dr. Takeshi Matsugi, Ms. Wakana Goto, Dr. Masaaki Kageyama, Dr. Hideaki Hara at Research \& Development Center, Santen Pharmaceutical Co., Limited for pharmacological evaluation of AFP-168.

Received: December 23, 2003

[1] a) R. Filler, Y. Kobayashi, 'Biomedicinal Aspects of Fluorine Chemistry', Kodansya and Elsevier Biomedical, Tokyo and Amsterdam, 1982; b) J.T. Welch, S. Eswarakrishman, 'Fluorine in Bioorganic Chemistry', John Wiley \& Sons, New York, 1991; c) R. Filler, Y. Kobayashi, L.M. Yagupolskii, 'Organofluorine Compounds in Medicinal Chemistry and Biomedical Applications', Elsevier, Amsterdam, 1993; d) I. Ojima, J.R. McCarthy, J.T. Welch, 'Biomedical Frontiers of Fluorine Chemistry', American Chemical Society, Washington, DC, 1996; e) T. Hiyama, 'Organofluorine Compounds, Chemistry and Applications', Springer, Berlin, 2000.

[2] a) J. Fried, E.F. Sabo, J. Am. Soc. Chem. 1954, 76, 1455; b) A. Wettstein, 'Ciba Foundation Symposium, Carbon-Fluorine Compounds, Chemistry, Biochemistry and Biological Activities', Elsevier, New York, 1972.

[3] V.P. Kukhar, V.A. Soloshonok, 'Fluorinecontaining Amino Acids: Synthesis and Properties', Wiley, Chichester, 1995.

[4] D.E. Bergstrom, D.J. Swartling, in 'Fluorine-Containing Molecules, Structure, Synthesis and Applications', Eds. J.F. Liebman, A. Greenberg, W.R. Dolbier, Jr., VCH, New York, 1988, p. 259.

[5] a) J.R. Vane, J. O'Grady, 'Therapeutic Applications of Prostaglandins', Edward Arnold, London, 1993; b) P.W. Collins, S. W. Djuric, Chem. Rev. 1993, 93, 1533.

[6] R.A. Coleman, W.L. Smith, S. Narumiya, Pharmacol. Rev. 1994, 46, 205.

[7] a) Y. Shimazaki, K. Kameo, T. Tanami, H. Tanaka, N. Ono, Y. Kiuchi, S. Okamoto, F. 
Sato, A. Ichikawa, Bioorg. Med. Chem. 2000, 8, 353; b) P.G. Klimko, T.L. Davis, B.W. Griffin, N.A. Scharif, J. Med. Chem. 2000, 43, 3400; c) T. Maruyama, S. Kuwabe, Y. Kawanaka, T. Shiraishi, Y. Shinagawa, K. Sakata, A. Seki, Y. Kishida, H. Yoshida, T. Maruyama, S. Ohuchida, H. Nakai, S. Hashimoto, M. Kawamura, K. Kondo, M. Toda, Bioorg. Med. Chem. 2002, 10, 2103; d) J.T. Whitson, Expert Opin. Pharmacother. 2002, 3, 965.

[8] S. Moncada, R.J. Gryglewski, S. Bunting, J.R. Vane, Nature, 1976, 263, 663.

[9] W. Skuballa, H. Vorbruggen, Angew. Chem. Int. Ed. Engl. 1981, 20, 1046.

[10] T. Murata, S. Sakaya, T. Hoshino, T. Umetsu, T. Hirano, S. Nishio, Arzneim. Forsch. 1989, 39 (II), 860.

[11] a) Y.J. Dong, R.L. Jones, N.H. Wilson, $B r$. J. Pharmacol. 1986, 87, 97; b) R.A. Armstrong, R.A. Lawrence, R.L. Jones, N.H. Wilson, A. Collier, Br. J. Pharmacol. 1989, 97, 657.

[12] a) T. Asai, Y. Morizawa, T. Shimada, T. Nakayama, M. Urushihara, Y. Matsumura, A. Yasuda, Tetrahedron Lett. 1995, 36, 273; b) Y. Matsumura, T. Shimada, T. Nakayama, M. Urushihara, T. Asai, Y. Morizawa, A. Yasuda, Tetrahedron, 1995, 51, 8771.

[13] a) Y. Matsumura, S-Z. Wang, T. Asai, T. Shimada, Y. Morizawa, A. Yasuda, Synlett 1995, 273; b) Y. Matsumura, T. Shimada, S-Z. Wang, T. Asai, Y. Morizawa, A. Yasuda, Bull. Chem. Soc. Jpn. 1996, 69, 3523.

[14] a) Y. Matsumura, T. Asai, T. Shimada, T. Nakayama, M. Urushihara, Y. Morizawa, A. Yasuda, T. Yamamoto, B. Fujitani, K. Hosoki, Chem. Pharm. Bull. 1995, 43, 353 ; b) Y. Matsumura, T. Nakano, T. Asai, Y. Morizawa, in 'Symposium Series 639, Biomedical Frontiers of Fluorine Chemistry', Eds. I. Ojima, J. R. McCarthy, J. T. Welch, American Chemical Society, Washington, D.C., 1996, p. 83.

[15] a) W.E. Barnette, J. Am. Chem. Soc. 1984, 106, 452; b) S.H. Lee, J. Schwartz, J. Am. Chem. Soc. 1986, 108, 2445; c) S. Singh, D.D. DesMarteau, S.S. Zuberi, M. Witz, H.-N. Huang, J. Am. Chem. Soc. 1987, 109, 7194; d) E. Differding, R.W. Lang, Helv. Chim. Acta 1989, 72, 1248; e) T. Umemoto, S. Fukami, G. Tomizawa, K. Harasawa, K. Kawada, K. Tomita, J. Am. Chem. Soc. 1990, 112, 8563; f) E. Differding, G.M. Ruegg, R.W. Lang, Tetrahedron Lett. 1991, 32, 1779; g) F.A. Davis, W. Han, Tetrahedron Lett. 1991, 32, 1631; h) E. Differding, H. Ofner, Synlett 1991, 187; i) G.S. Lal, J. Org. Chem. 1993, 58, 2791.

[16] T. Nakano, M. Makino, Y. Morizawa, Y. Matsumura, Angew. Chem. Int. Ed. Engl. 1996, 35, 1019.

[17] W. Skuballa, E. Schillinger, C.S. Stuerzebecher, H. Vorbruggen, J. Med. Chem. 1986, 29, 313

[18] S. Iguchi, H. Nakai, M. Hayashi, H. Yamamoto, K. Maruoka, Bull. Chem. Soc. Jpn. 1981, 54, 3033.

[19] W. Kirmse, A. Wonner, A.D. Allen, T.T. Tidwell, J. Am. Chem. Soc. 1992, 114, 8828

[20] C.-S. Chan, M. Negishi, T. Nakano, Y. Morizawa, Y. Matsumura, A. Ichikawa, Prostaglandins 1997, 53, 83.
[21] A.K. Sim, M.E. Cleland, A.B. Pottage, Y. Matsumura, T. Nakano, 10th International Conference on Prostaglandins and Related Compounds, 1996, Vienna.

[22] L. Alger, M. Geraci, R.M. Tuder, N.F. Voelkel, 'Abst. of the 91th International Conference of the American Heart Association and American Thoracic Society' C46-K7, 1998, Chicago.

[23] L.Z. Bito, Exp. Eye Res. 1984, 40, 181.

[24] a) M. Sakurai, M. Araie, T. Oshika, M. Mori, K. Masuda, R. Ueno, M. Takase, Jpn. J. Ophthalmol. 1991, 35, 156; b) B. Resul, J. Stjernschantz, K. No, C. Liljebris, G. Selen, M. Astin, M. Karlsson, L.Z. Bito, J. Med. Chem. 1993, 36, 243; c) P.A. Netland, T. Landry, E.K. Sullivan, R. Andrew, L. Silver, A. Weiner, S. Mallick, J. Dickerson, M.V. Bergamini, S.M. Robertson, A.A. Davis, Am. J. Ophthalmol. 2001, 132, 472; d) R.F. Brubaker, E.O. Schoff, C.B. Nau, S.P. Carpenter, K. Chen, A.M. Vandenburgh, Am. J. Ophthalmol. 2001, $131,19$.

[25] a) P.G. Watson, J. Stjernschantz, Ophthalmology 1996, 103, 126; b) G. Prota, M.R. Vincensi, A. Napolitano, G. Selen, J. Stjernschantz, Pigment Cell Res. 2000, 13, 147.

[26] Y. Takagi, T. Matsugi, M. Kageyama, A. Shimazaki, Y. Matsumura, H. Hara, Invest Ophthalmol Vis Sci. 2003, 44, 4407.

[27] E.W. Yankee, U. Axen, G.L. Bundy, J. Am. Chem. Soc. 1974, 96, 5865.

[28] a) E.J. Corey, S. M. Albonico, U. Koelliker, T.K. Schaaf, R.K. Varma, J. Am. Chem. Soc. 1971, 93, 1491; b) D. Binder, J. Bowler, E.D. Brown, N.S. Crossley, J. Hutton, M. Senior, L. Slater, P. Wilkinson, N.C.A. Wright, Prostaglandins, 1974, 6, 87; c) T.K. Schaaf, J.S. Bindra, J.F. Egger, J.J. Plattner, A.J. Nelson, M.R. Hohnson, J.W. Constantine, H-J. Hes, J. Med. Chem. 1981, 24, 1353.

[29] Recently, fluorination of 1,2-dibenzoylethylene with Deoxofluor was reported to give a mixture of the corresponding difluoro and tetrafluoro compounds. See R.P. Singh, U. Majumder, J.M. Shreeve, $J$. Org. Chem. 2001, 66, 6263.

[30] L.N. Markovskii, V.E. Pashinnik, A.V. Kirsanov, Synthesis, 1973, 787.

[31] Y. Matsumura, N. Mori, T. Nakano, H. Sasakura, T. Matsugi, H. Hara, Y. Morizawa, Tetrahedron Lett. 2004, 45, 1527.

[32] K. Kashiwagi, K. Tsukamoto, M. Suzuki, S. Tsukahara, J. Glaucoma. 2002, 11, 57.

[33] T. Nakajima, T. Matsugi, W. Goto, M. Kageyama, N. Mori, Y. Matsumura, H. Hara, Biol. Pharm. Bull. 2003, 26, 1691. 